\title{
A Situated Evaluation of the Egyptian Primary School EFL Textbook "Time for English"
}

Marwa Gamal M. Shehata

Jamal Hamed Jahin

\section{Abstract}

Textbooks play a very important role in many language classrooms, especially in the Egyptian EFL context. Therefore, the textbook used must surely be appropriate to its target users (i.e. learners, teachers, supervisors, etc.) and above all must be fit for the context in which it is used. The purpose of this study is to evaluate Time for English, the EFL textbook series used in Egyptian governmental primary schools from the perspectives of primary school EFL teachers in context. The study made use of the mixed-method research design. Data were collected from two sources. The first was Textbook Evaluation Checklist (TEC) which was an adapted form from Litz (2005). The adapted TEC addressed eight aspects of textbook evaluation. These are: physical make-up, layout and design, supplementary materials, activities and exercises, skills and sub-skills, language type, subject and content, and context. The TEC was administered to an opportunity sample of 216 primary school EFL teachers belonging to five governorates in Lower Egypt. The second was semi-structured interviews that were conducted with a subsample drawn from the TEC sample (n.=44). Findings of both quantitative and qualitative data analyses indicated that Time for English proved to have had a lot of pitfalls related to layout and design; supplementary materials; activities and exercises; skills and sub-skills; language type; subject and content; and context. Further results of qualitative data analysis indicated that a series of constraints acted against the feasibility of Time for English and suggestions to overcome these constraints were discussed. The results have clear implications for EFL curriculum and syllabus designers. The study findings provided a set of recommendations related to school EFL textbook selection and adaptation, and EFL teacher training. Finally, suggestions for further research are presented.

Keywords: Situated EFL textbook evaluation; EFL textbook evaluation checklist; primary EFL

\section{Introduction}

Due to the important role played by textbooks in the teaching and learning process, especially in formal school settings, educationalists worldwide have been obsessed by textbook evaluation. The purpose is to make sure that the 'textbook' (or the teaching/learning material) is the best possible fit for the target consumers as well as the context in which it will be/is being used. This is manifestly pertinent in EFL contexts where most of the

\section{3}


textbooks in the teachers' and school children's hands worldwide are developed by native English language speaking authors. In EFL contexts, the textbook is the main, if not the only, teaching/learning material available, something that signifies the essential role played by EFL textbooks. The EFL textbook is sometimes referred to as the syllabus or the whole curriculum that, by virtue, dictates not only what to teach but how to teach this 'what' as well.

In Egypt, school EFL textbooks are conventionally taken for granted. The teachers as well as the learners work according to the textbook. Hence, the textbook serves as a syllabus because it is followed systematically so as to cover a carefully planned and balanced selection of language content. Consequently, the EFL teacher within the Egyptian context is not allowed to have any freedom to adapt or supplement the textbook when necessary.

Within the Egyptian context, it has been habitually underway that publishing companies take guidance from the national standards of teaching and learning EFL and compete against one another to offer what is believed to be the 'best' possible teaching/learning materials that might potentially be approved and selected by the officials in the MOE. Once a textbook is officially selected, a syllabus is drawn up. Hence, the normal process of drawing up a syllabus and then looking for the 'best' possible teaching/learning material that can help achieve the learning outcomes based in the standards is reversed. This helps to create problems arising from the possibility that the selected textbook does not in reality represent the 'best possible fit' for the target consumers or that the chosen textbook itself, though being welldesigned has pitfalls. This is due to the fact that after the decision has been made concerning the choice of a certain course book from the variety of the teaching materials available in the publishing market, a step forward is taken to write down the directives for teachers of English at the level to which the course book will be assigned. These directives are distributed by the supervisors of English to the school teachers under their supervision. These directives include detailed information about

\section{4}


what the students should learn and how it should be taught. Consequently, there are no clear-cut borders between the syllabus and the textbook but there is 'mixture' of what the official authorities in the Ministry of Education see (i.e. the goals and objectives of teaching English in Egypt) and what the textbook seeks to achieve. Having said that, the course book lays out all the language content/input teachers have to teach, as well as the ways of teaching it. It also gives them texts, exercises and ideas for activities. In this respect, Ur (1996: 181) argues;

"When only one course book can be afforded per student, the book often tends to take over the function of a syllabus, particularly if the book has been recommended for use by the same authority that drew up the syllabus.

\section{The Context in Egypt}

In the Egyptian situation, syllabus design and curriculum development of all school subjects are the responsibilities of the Counselor's Office in collaboration with Centre for Curriculum and Instructional Materials Development (CCIMD). Once the syllabus is designed for implementation, guidelines for publishers and textbook authors are prepared by the relevant subject specialists to define all principles and criteria to help them produce good quality textbooks in support of and in line with the recommended syllabus. This situation applies to EFL school textbooks. Once the syllabus for each school level is drawn, publishing companies compete to produce textbooks that can hopefully achieve the intended syllabus objectives. Since a new English language textbook is being utilized in the primary cycle of basic education (age group 6-12), it passes through close and detailed examination or evaluation as to its physical appearance; layout and design; supplementary materials; activities and exercises; skills and sub-skills; language type; subject and content; and context.

Considering the position of EFL learning materials in Egypt, the Ministry of Education traditionally approves and dictates textbooks to all governmental schools nationwide. Teachers are expected to 'teach the textbook' and implement methodologies that they recommend.

\section{5}




\section{Context of the problem}

In Egypt during the school year 2013-2014 and with no preliminary orientations, an official decision was taken to withdraw the primary school previous EFL textbooks "Hand in Hand" from grades ( 1 - 3 ) and "Hello" from grades (4-6), and replaced them by "Time for English" (TFE) which is an adaptation of "English Time" course by Susan Rivers and Setsuko Toyama that was originally published by Oxford University Press. Adaptation was made by two local ELT experts, and publishing was carried out by Dar AlShorouq, a local publisher. This sudden mandating of "Time for English (TFE)" to all grades of the primary school proved to have triggered complaints all over the country from all types of stakeholders including primary school EFL teachers. In response, feedback from all over the country was sent to the MOE. What makes matters worse is that the textbook was dictated by the MOE without prior training of the EFL teachers or analysis of the specific characteristics of the context in which the new textbook would be hosted. In response to the nationwide complaints arising against the newly introduced textbook, the MOE organized a series of workshops that were jointly conducted by the Centre for Curriculum and Instructional Materials Development (CCIMD) and the National Centre for Educational Evaluation and Examinations (NCEEE) with the aim of sorting out the problematic situation resulting from the sudden intervention of the new textbook. Attempts were made to simplify the exam specifications for all grades. Besides, a pilot study was conducted nationwide through a series of videoconference sessions with primary school EFL teachers. Criticisms launched against TFE were basically focused on teachers' lacking of knowledge and skills to teach the content; the bumpiness of the inappropriate physical layout; etc. In response to the feedback arising from the field came out an official need to empirically evaluate the TFE from the perspectives of the actual practitioners and its immediate customers.

\section{Statement of the problem}

A state of dissatisfaction with Time for English has been increasingly underway. Focus in this study is placed on evaluating

\section{6}


the status quo by illuminating the scene and identifying the problematic issues that Time for English might be experiencing from the perspectives of EFL teachers. Evaluation of Time for English carried out by the study is not context-devoid. Rather, evaluation is aimed to be context-based and situated with the daily realities of primary school EFL teachers.

\section{Research questions}

The purpose of this study is to assess the effectiveness of the primary school EFL textbook titled "Time for English" (TFE), which was prepared by Ministry of Education as an instructional material for the six grades of the primary school in Egypt, from the perspectives of primary school EFL teachers. The specific research questions are listed below:

1. To what extent is TFE effective according to physical make-up, as seen by EFL teachers?

2. To what extent is TFE effective according to layout and design, as seen by EFL teachers?

3. To what extent is TFE effective according to supplementary materials, as seen by EFL teachers?

4. To what extent is TFE effective according to activities and exercises, as seen by EFL teachers?

5. To what extent is TFE effective according to language skills and sub-skills, as seen by EFL teachers?

6. To what extent is TFE effective according to language type, as seen by EFL teachers?

7. To what extent is TFE effective according to subject and content, as seen by EFL teachers?

8. How far is TFE suitable for the Egyptian context, as seen by EFL teachers?

\section{Purpose}

This study aims to ascertain primary school EFL teachers' perspectives of the effectiveness of current primary school EFL textbook- 'Time for English' - in terms of physical make-up; layout and design; supplementary materials; activities and exercises;

\section{7}


language skills and sub-skills; the language type; subject and content; and suitability for the Egyptian context. An attempt made by this study is to ascertain the participants' perspectives from the interpretive-constructivist research paradigm.

\section{Significance}

The expected significance of this study emerges from the following points:

1. The results of the evaluation of the EFL textbook are expected to illuminate the situation for the MOE program developers to make more precise decisions on selecting more appropriate EFL textbooks for the primary school in the future.

2. The textbook evaluation is conducted by primary school EFL teachers themselves. This helps them to move beyond the impressionistic assessments and get useful insights into the practicality of the textbook itself.

3. The results of the evaluation are expected to give feedback to EFL teacher education and training programmes developers. Based on the results, the actual world that EFL teachers experience will be exposed and become more meaningful for EFL teacher educators so as to tailor teacher education programmes that would cater for EFL teachers' needs and the actualities that they live in.

4. Evaluating Time for English is expected to provide teachers and their supervisors with insight into the suitability or applicability of particular approaches or techniques advocated by the textbook in their practical context of teaching.

5. Since Time for English marks the first step for primary school children in the realm of English language learning, it is important to make sure that the textbook is engaging enough to excite children's interests and presenting the fundamentals of English in an age-appropriate manner.

6. The findings may contribute to the studies related to ELT materials evaluation, curriculum development and ELT course design. The feedback gained will provide more insight into the suitability of other EFL textbooks taught at preparatory and secondary schools.

\section{8}


7. The evaluation would help textbook designers and publishers by illuminating the context in which their teaching and learning materials or textbooks are hosted.

\section{Delimitations}

This study is targeting primary school EFL teachers in five governorates located in Lower Egypt: Cairo, Giza, Qalyubiya, Sharkia and Dakahliya. Therefore, conclusions need to be verified by conducting similar studies across other governorates, especially those based in Upper Egypt. It is assumed that teachers answered the questions honestly and with seriousness. The study does not include pupils' perspectives of the textbook because they may not be as knowledgeable or expressive in the language of ELT as their teachers. In addition, the study does not address supervisors' perceptions of the textbook despite their significance, since the aim is to get hold of the actual practitioners and the first-hand users of the textbook (i.e. the EFL teachers).

\section{Review of literature}

\section{Role of textbooks in EFL contexts}

The role played by textbooks has been an essential issue investigated by authors worldwide. The textbook provides texts and learning tasks which are likely to be implemented in the class. This, of course, saves time for the teacher and compensates the inefficiency of the language teacher to prepare materials. Ur (1996) asserted that a syllabus can be a source of information and that it supports teachers who are not confident enough of their knowledge of the target language. Besides, Nunan (1988) noted the functional role of materials as follows:

"Materials are, in fact, an essential element within the curriculum, and do more than simply lubricate the wheels of learning. At their best, they provide concrete models and at their very best they fulfill a teacher development role." (p.98).

This explains why evaluating the textbook used in the classroom is a very important issue for the learning/teaching process. In the above sense, especially in EFL contexts, evaluation of an EFL textbook represents an evaluation of the whole curriculum since the textbook is considered 'the curriculum'

\section{9}


and consequently, "textbooks have become so important that almost all concern about the curriculum finds its focus in concern about the textbooks used" Woodward, Elliot 1990). In the same line the textbook represents a replacement for curriculum, "a reflection of a sometimes undocumented curriculum that may also be only partially specified" (Venezky, 1992: 439). This is summed up by a set of questions posed by Richards (2016) in his explanation of the role of textbooks in a language programme. The questions include (1) "Is there a well-developed curriculum that describes the objectives, the syllabus and content of the program or will this be determined by the textbook?" and "will the book or textbook series provide the core of the program, or is it one of several different books that will be used?"(p.3).

Highlighting the multiple roles of textbooks, Cortazzi and Jin (1999) suggested that the textbook can be a teacher, a map, a resource, a trainer, an authority, and an ideology. The language textbook was also described as a resource and a source for learners to practice and do the activities. Moreover, the language textbook supports teachers, especially novice or inexperienced ones, by providing them with more confidence and security (Cunningsworth, 1995). In the above sense, the language textbook serves both learners and teachers by providing the former with the necessary input and the language practice and the latter with an opportunity for training (Richards, 2001).

\section{Reasons for evaluating textbooks}

Different reasons were given for evaluating English language teaching materials. For example, Hutchinson and Waters (1987) saw that textbook evaluation is an analytical process of "Matching needs to available solutions" (p. 97). This, they suggested, can be done according to the sponsor's needs through a needs analysis process. While this perspective is important, it is incomplete since it disregards other interested parties, such as teachers and learners. Since situated textbook evaluation helps to show how a textbook is used and how it can be improved, it has become an educational necessity. Moreover, the growing impact that teaching materials have had on the process of learning and teaching prompted authors, such as Nunan (1988), to state that textbooks

\section{0}


or materials are curriculum models and, at their very best, they fulfill a teacher development role. In this sense, evaluating a certain EFL textbook implies the evaluation of the whole EFL curriculum. Two main reasons for evaluating a textbook were given by Weir and Roberts (1994). The First, textbook evaluation provides evidence which can inform theoretical disputes about directions to be followed in language teaching or in teacher education. Second, textbook evaluation is a tool to indicate the suitability of particular approaches or techniques and whether they meet the objectives made for them. Whatever the reasons given for materials or textbook evaluation are, they stem from "a sense of dissatisfaction" (Harmer, 1998: 276) with what is happening. Ellis (1997) distinguished between two types of materials evaluation in terms of purpose: predictive evaluation, which aims to make a decision regarding what materials to use, and retrospective evaluation, which aims to examine materials that have actually been used.

The arguments posed above provide different reasons for textbook evaluation and apply, though not exclusively to the Egyptian context since every educational context has its own specificity. That the EFL textbook represents, at least for both teachers and school students, the whole curriculum is one of these reasons. Besides, the dilemma created due to the sudden introduction and mandating of TFE to the state primary schools made it necessary to carry out this evaluation study in an attempt to sort out the problematic issues surrounding the feasibility of this textbook from different aspects. In this respect, it is not out of a concern of "Matching needs to available solutions", as Hutchinson and Waters (1987) indicated above. Rather, it has been triggered by the need to ascertain the extent to which TFE is feasibly teachable, especially when we know that it has been recently adapted for the Egyptian state primary schools.

\section{Textbook Evaluation: Checklists}

Since any set of commercially produced teaching materials would be unlikely to be completely suitable for a particular group of learners (McGrath, 2002 and McDonough \& Shaw, 2003) and

\section{1}


that the "the evaluation of materials should be as formal and principled as possible" (Harmer, 1998, p. 279), the need for a systematic approach to textbook evaluation arose. A number of authors developed textbook evaluation checklists. Examples included Williams (1983); Breen and Candlin (1987); Sheldon (1988); Cunningsworth (1995); Ur (1996); Harmer (1998); McDonough and Shaw (2003); McGrath (2002); Litz (2005); Tok (2010); etc. Besides, the advantages and disadvantages of checklists have been pointed out by several writers. Advantages included cost and time-effectiveness; understandability of the results obtained; and the potential of replicability and comparability. On the other hand, disadvantages included datedness, lack of criteria transparency (McGrath, 2002). The pros and cons of using a checklist underpin Sheldon's (1988) suggestion that "no general list of criteria can ever really be applied to all teaching and learning contexts without considerable modification, most of these standardized evaluation checklists contain similar components that can be used as helpful starting points for ELT practitioners in a wide variety of situations" (p.238). However, "most of these standardized evaluation checklists contain similar components that can be used as helpful starting points for ELT practitioners in a wide variety of situations" (Papajani, 2015:8).

According to Ansary and Babaii (2002), the fundamental problem with textbook evaluation checklists is that they depend on the swings of one's own propositions and priorities. Namely, decisions on what criteria to include in a textbook evaluation checklist would depend mostly on one's own priorities. For example, textbook evaluator orientated with a structural syllabus would give priority to 'grammar' component in his/her checklist. On the other hand, an evaluator orientated with a functional syllabus would give more priority to 'activities and language practice'. This unclear situation justifies the relative merits and demerits of ready-made such checklists.

\section{Studies on EFL Textbook Evaluation}

A number of studies have been conducted on textbook evaluation throughout the world which represents their great

\section{2}


significance in language teaching and learning. Most researchers have included the criteria such as aims, approach, layout, design, content, subject, language, practical considerations, activities, and skills in their model. Other researchers have evaluated course books in comparison with each other. Ranalli (2002) evaluated upper-intermediate New Headway taught at the Foreign Language Institute of Yunsei University in Korea. He showed that the textbook adheres to a 'present-practice-produce' learning approach and that the units of the book provide a semi-authentic context for the target language patterns. Kayapinar (2009) - citing Alemi \& Sadehvandi - studied two textbooks: Opportunities and New English File. He found that the teachers had not positive attitudes towards those course books. Dominguez (2003) examined the representation of gender in both texts and examples of New Interchange Intro. She concluded that the textbook is a valuable source for teachers and that the textbook has been successful in considering learners' settlement and integration needs, particularly at beginner levels, and providing a balance in depicting the two genders. Litz (2005) investigated 'English Firsthand 2' used in Suwon, South Korea, to check its appropriateness for the intended language program. He found that the textbook was interesting enough for many English language teachers and learners and that the textbook was generally communicative. Tok (2010) studied the weaknesses and strengths of the EFL textbook 'Spot On' taught at primary schools in Turkey. His findings indicated that the negative attributes of the textbook outweighed highly its positive characteristics.

Some comparison studies in the domain of textbook evaluation have also been conducted. Vellenga (2004) made a comparison between EFL and ESL textbooks. The findings revealed EFL texts incorporated more pragmatic information although the amount of pragmatic information was not enough across all texts. Jahangard (2007) in his analysis of high school EFL textbooks found a lack of correspondence between the presented vocabulary items. He suggests that using colorful pictures of real people and real environment can enhance the attraction of the books. Sahragard, Rahimi and Zaremoayyedi (2009) evaluated a series of ELT

\section{3}


materials namely, Interchange. They found that learners were not the initiators of the tasks. Moreover, Azizfar, Koosha, and Lotfi (2010) evaluated Iranian high school English textbooks and found that the designers have just focused on the mechanical drills. In Turkey, Hamiloglu and Karliova (2009) examined five selected English language textbooks focusing on vocabulary selection and the teaching techniques they employed. They found that the course books integrated lexis into their syllabuses and used separate headings and sub-headings such as vocabulary, word formation, and word building to focus on vocabulary knowledge.

The above review of EFL textbook evaluation research studies shows that each study adopted a certain perspective and rationale in textbook evaluation. However, they together reflect a worldwide concern with EFL textbook evaluation.

\section{Situated EFL textbook evaluation: A definition}

The situated evaluation of the primary school EFL textbook adopted by this study is meant to be an "in-use reflective, constructivist evaluation, addressing both internal and external aspects of textbook; it is context-based and situated in the localities of teachers' day-to-day lives as well as their subjectively build-in perspectives."

\section{Method Design}

This study adopted the interpretive-constructivist research stance. In view of the exploratory nature of this study, the naturalistic orientation of qualitative research appeared to be an appropriate choice. The aim is to understand actualities; social realities and human perceptions that exist untainted by the unobtrusiveness of formal measurement or preconceived questions. The aim is to uncover the many idiosyncrasies and present 'slice-of-life' episodes documented through natural language to represent as closely as possible how people feel, what they know, and what their concerns, beliefs, perceptions and understandings are. The study aims to come to grips with two kinds of social reality. The first is teachers' subjectively expressed evaluation of Time for English based on their lived experiences.

\section{4}


The second is the extent to which teachers' evaluations are rooted in their context. In the interpretive-constructivist mode of inquiry, the informants articulate their definitions of their situations, something that renders the natural social world intelligible (Denzin \& Lincoln, 2011). On the other hand, the in-depth nature of the inquiry means that the findings give insightful explanations of a phenomenon, which could be useful to other people in similar situations (Barbour, 2014).

\section{Data collection}

\section{Instrumentation and Sampling}

The data were collected from two main sources, representing the two phases of data collection. These are the Textbook Evaluation Checklist and the semi-structured interviews. An overview of each phase is given below.

\section{Phase one: Textbook Evaluation Checklist (TEC)}

After a close examination of a set of checklists used in similar contexts and taking into consideration the specificity of EFL teaching/learning context in Egypt, a decision was taken to adapt a textbook evaluation checklist used by Litz (2005) in the South Korean EFL context which is similar to the EFL Egyptian context in many aspects. The adapted checklist is based on the basic criteria by which different aspects of the current primary school EFL textbook Time for English will be analyzed and evaluated. Besides, the specificity of the Egyptian EFL teaching-learning situation and textbook mandating enterprise was catered for. Adapting a textbook evaluation checklist was thought necessary to use for the local situation because, as Sheldon (1988) states, "textbook criteria are emphatically local" (p.241). Doing otherwise would have led to the use of a ready-made textbook evaluation checklist that might have provided unrealistic picture of reality. The original form consisted of questions that pertained to the practical considerations, layout and design, activities, skills and language type. The adapted format of checklist paid attention to the specificity of the Egyptian context, including teacher quality; school potentialities; teacher's workload; examination system; and the Egyptian context and culture. The final format of the TEC comes in eight sections, as follows: (1) Physical make-up; (2)

\section{5}


Layout and design; (3) Supplementary materials; (4) Activities and exercises; (5) Skills and sub-skills; (6) Language type; (7) subject and content; and (8) Context (See Appendix 1). The content validity of the TEC was verified. Initial layout of the TEC was validated by a group of jury who provided valuable feedback on its design, wording and components until the final format was reached. Then the TEC was translated from English into Arabic by two independent professional translators and their translated versions were compared until reliability of translation was established. To establish the reliability of the TEC the test-retest method was used. It was administered twice, with an interval of five weeks, to a sample of EFL teachers similar to the target participants of the main study. Responses to both administrations were compared and the Cronbach Alpha coefficients were calculated for the TEC as a whole and for each of the subsections. All coefficients proved to be satisfactory indicating high levels of reliability for the TEC as a whole (0.9527) and its subsections. A number of 350 primary school EFL teachers working in governmental schools based in five governorates in Lower Egypt were targeted. Three-hundred fifty copies of the TEC were distributed equally to the five governorates. However, only 216 valid responses were obtained representing a response rate of $62 \%$. Since opportunity sampling approach was used, the participants belonged to different ranges of teaching experience, and to different initial teacher education backgrounds. Distribution of the TEC sample and the focus-group interviews to the five governorates is represented by table (1) below.

Table (1) Distribution of the TEC sample to the five governorates

\begin{tabular}{|c|c|c|c|}
\hline & Governorates & Targeted by TEC & Correct TEC responses \\
\hline 1 & Cairo & 70 & $56(80 \%)$ \\
\hline 2 & Giza & 70 & $48(69 \%)$ \\
\hline 3 & Qalyoubiya & 70 & $33(47 \%)$ \\
\hline 4 & Sharkia & 70 & $49(70 \%)$ \\
\hline 5 & Daqahliya & 70 & $30(43 \%)$ \\
\hline
\end{tabular}

1. Phase two: The semi-structured focus-group interviews

At phase two of the study interviews with the sub-samples of teachers aimed to ascertain, contextualize and situate their articulated evaluations of the current EFL textbook, Time for English and their perceptions of its teachability in the Egyptian

\section{6}


context. Namely, they aimed to ascertain how the participants construe their views of the world and make sense of their experiences, since they are the immediate practitioners and users of the textbook under evaluation. Interviews were guided by a protocol which was developed by the researchers and facevalidated by a group of jury whose area of interest is ELT coursebook design and coursebook selection. The protocol was then tried out with two EFL teachers (See Appendix 2) and its final layout was used with five cohorts of participants (one cohort in each governorate) in a focus-group semi-structured format. Each cohort consisted of seven participants with the exception of the group based in Sharkia governorate which consisted of nine participants. The interviews were recorded and transcribed, and transcripts were respondent-validated via emails with a representative of each group for further analysis. Though interviews were guided by a protocol, interviewees were given full freedom to articulate their experiences. They sometimes tended to remind one another of how the textbook under evaluation is being used and processed. Most importantly articulated responses focused on the practicability and feasibility of Time for English with more interest in how to make its use a success. Thus, throughout the interviews informants tended to provide solutions for the immediate day-to-day problems associated with using Time for English. Anecdotes were recurrent in their articulation of their perceptions, something that helped to substantiate their espoused evaluations and throw more authenticity on the collected data.

\section{Data analysis}

Quantitative analysis using SPSS Software (version 22) was carried out to analyze EFL teachers' responses to Textbook Evaluation Checklist (TEC). The semi-structured focus-group interview data representing the participants' articulated perspectives and evaluations of Time for English were analyzed using the grounded theory approach (Charmaz, 2008). The rigorous coding scheme of the grounded theory method yielded a set of categories. Major themes that emerged under these categories match the TEC categories. Each of these themes will

\section{7}


be presented in conjunction with its parallel TEC section. Further themes like "dissatisfactions with TFE" and "suggested solutions" emerged from the data. Articulated evaluations related to each of these themes help to add more depth and yield more insight into the feasibility, practicability and teachability of TFE. This helps to justify why things the way they are, thus helping to contextualize teachers' overall evaluation of TFE. In some cases, these voiced evaluations coincide with the TEC responses while they contradict with them in other cases. Live interview quotes were translated into English by the researchers and translation was cross-checked by another independent translator.

\section{Results}

Presentation of the results below will follow the same order of the research questions of the study. Quantitative data are presented in tables and matched by short explanations where possible. Following the results of the quantitative analysis of each section live quotes from the semi-structured interviews will be provided. Mixing quantitative with qualitative data was done purposefully for two purposes. The first was that the qualitative data help to crosscheck and validate the quantitative data. The second is that, in some instances, the qualitative data help to add more depth to the quantitative data.

\section{Research question no. 1:}

To what extent is TFE effective according to physical make-up, as seen by teachers?

Table (2) below shows that teachers gave varied responses related to different aspects of the textbook make up. The appropriacy of the book size and weight came first followed by the appropriacy of the textbook title. The cover and overall appearance were seen as appealing by a large number of the participants. On the other hand, figures indicate that there are problems with the quality of editing and publishing.

Table (2) Teachers' Evaluation of the Physical Make-up of TFE

\section{8}


Number 69, Part 2 January, 2015

\begin{tabular}{|c|c|c|c|c|}
\hline & Concerning Physical make-up, I think that ...... & Mean & SD. & Rank \\
\hline 1 & The cover of the textbook is appealing. & 2.59 & .604 & 3 \\
\hline 2 & $\begin{array}{c}\text { The size and weight of the textbook is } \\
\text { appropriate. }\end{array}$ & 2.79 & .453 & 1 \\
\hline 3 & $\begin{array}{c}\text { The overall appearance of the textbook is } \\
\text { appealing to pupils. }\end{array}$ & 2.50 & .647 & 4 \\
\hline 4 & The textbook title is appropriate. & 2.72 & .536 & 2 \\
\hline 5 & $\begin{array}{c}\text { The textbook is of high quality of editing and } \\
\text { publishing. }\end{array}$ & 2.33 & .715 & 7 \\
\hline 6 & $\begin{array}{c}\text { The font type and size used in the textbook are } \\
\text { appropriate for the pupils. }\end{array}$ & 2.45 & .652 & 6 \\
\hline 7 & $\begin{array}{c}\text { The illustrations are simple and close enough } \\
\text { to the text that they add to its meaning. }\end{array}$ & 2.47 & .727 & 5 \\
\hline 8 & $\begin{array}{c}\text { There are language, technical and typo errors } \\
\text { in the textbook. }\end{array}$ & 1.50 & .735 & 8 \\
\hline
\end{tabular}

Participants' responses related to the physical make-up of the textbook were cross-checked by their views articulated in the interviews. Their responses focused on two main themes: these are dullness of pictures and quality of printing. Each of these two themes is delineated through live interview quotes below.

\section{Dullness of pictures}

One of the factors which increase students' motivation in class activities is using colorful pictures in textbooks. Pictures, as visual illustrations and organizers of learning, should be appealing enough to motivate learners to engage in the learning process. However, with Time for English the situation is quite the opposite as expressed by the following two exemplary comments by teacher participants:

"The pictures used in the book aren't of good quality. They are not of the proper size and they are not clear. Even pupils themselves have noticed this. They all the time compare between the quality of pictures they have in their books and those they see in the outside commercial course books".

Colour also plays a vitally important role in the way textbooks are handled and their readability and understandability. The colour of pictures used in textbooks should be appealing to pupils' interests; otherwise, they cannot be motivating to learning. Omar, one of the participating teachers, noticed a mischief with colour:

\section{9}


"The authors have not used colors in this textbook effectively. In most of the pictures, the colour are interchangeable. They are not precise. The text may be asking or talking about the blue sky while in the picture the sky is red or green. This is a big problem throughout the whole textbook at all grades".

\section{Quality of printing}

Complaints from almost all teachers were raised against the bad quality of the textbook printing. This was because the textbook was printed by local and small printing bookshops. Two exemplary related comments are given below:

"This is not printed by the Longman or even the MOE printing house. It is printed by small printing houses that are authorized by delegation to print it. This is why the quality of paper is very bad. The colouring is not professional and not clear".

"The pictures are sometimes placed as form of just colouring the text. They are sometimes misplaced, and they are not necessary in other places. They should add something to the text".

The font type and size was a common complaint amongst the informants as expressed below:

"Look at the size of the font. Normally, as is the case with all school subjects at the primary stage, the font size should be comfortable for the child's eye, should be big enough. As we see, sometimes the font is too difficult to recognize even for me as a teacher".

\section{Research question no. 2}

To what extent is TFE effective according to layout and design, as seen by teachers?

Table (3) shows that teachers gave varied responses related to different aspects of the textbook layout and design. The appropriacy, clarity and the organization of the textbook design and layout in addition to the clarity of the textbook objectives for both the teacher and pupils are the top three aspects favored by teachers.

\section{0}


Table (3)Teachers' Evaluation of the Layout and Design of TFE

\begin{tabular}{|c|c|c|c|c|}
\hline & Concerning Layout and Design, I think that... & Mean & SD. & Rank \\
\hline 1 & $\begin{array}{c}\text { The textbook includes a detailed overview of the } \\
\text { functions, structures and vocabulary that will be } \\
\text { taught in each unit. }\end{array}$ & 2.31 & .760 & 3 \\
\hline 2 & The layout and design is appropriate and clear. & 2.40 & .689 & 1 \\
\hline 3 & The textbook is organized effectively. & 2.32 & .712 & 2 \\
\hline 4 & $\begin{array}{c}\text { An adequate vocabulary list or glossary is } \\
\text { included. }\end{array}$ & 2.22 & .768 & 4 \\
\hline 5 & $\begin{array}{c}\text { Adequate review sections and exercises are } \\
\text { included. }\end{array}$ & 2.12 & .780 & 6 \\
\hline 6 & $\begin{array}{c}\text { An adequate set of evaluation quizzes or testing } \\
\text { suggestions is included. }\end{array}$ & 1.99 & .772 & 7 \\
\hline 7 & $\begin{array}{c}\text { The teacher's book contains guidance on how the } \\
\text { textbook can be used to the utmost advantage. }\end{array}$ & 2.15 & .783 & 5 \\
\hline 8 & $\begin{array}{c}\text { The materials objectives/learning outcomes are } \\
\text { apparent to both the teacher and student. }\end{array}$ & 2.31 & .675 & 3 \\
\hline
\end{tabular}

On the other hand, most teachers complained about unavailability of the teacher's book at their respective schools. Besides, the review sections and quizzes that are essential for recycling the learned material are not enough.

Teachers' articulations related to textbook design and layout focused in some cases on the lacking of guidance on how the textbook should be handled due to shortage of the teachers' book and in other cases on the need to have more evaluation sections. This is clearly articulated through the following comments.

"We don't have the teacher's book. Actually we learn how to teach English by experience, you know as we were taught, I mean, when we were school pupils. You know since we got the job, I've never had used the teacher's book, because it isn't available. The Ministry shouldn't forget that the teacher needs a catalogue to know how to deal with the textbook".

The lack of guidance becomes more serious, especially when the supervisor's role becomes superficial and almost nonexistent.

"We don't have anything valuable from the supervisor's visit. She just comes to the school may be once a month without prior notice to sign some papers, and that's it. Sometimes, she visits us in the classroom but she herself doesn't have something worthwhile to give. She supervises us in the way she was taught, Ahhhh....you know from experience". 
Even in case that the teacher's guide is available, constraints based in the school and classroom environments always act against acting upon its idealities. This is due to lack of facilities, lack of time, untrained teachers....etc.

"Yes, it's been useful in some cases. But in most cases you feel like it is talking to teachers from the Mars and not to teachers like us living on earth. See how many pupils I have in the classroom. How can I use pair work or group work and how can I correct their mistakes or even mark their homework sheets or workbook exercises. The reality is different. There isn't enough time".

Teachers complained about the inadequacy of evaluation sections both in the pupil's book and the workbook. This is represented in both the amount of evaluation and recycling sections and the layout of these exercises.

"The textbook in its present state doesn't help pupils to pass the tests or final exams. The specifications of the exams from the ministry are different. So, there is no other option but to rely on the 'outside books' that do what the school textbooks don't. They contain a big amount of exercises and practice tests. They buy them two months before the school year starts".

\section{Research question no. 3}

To what extent is TFE effective according to supplementary materials, as seen by teachers?

Table (4) below shows that teachers gave varied responses related to the textbook supplementary materials. For example, the importance of the teacher's guide is highly represented in teachers' responses.

Table (4) Teachers' Evaluation of the Supplementary Materials of TFE

\begin{tabular}{|c|c|c|c|c|}
\hline & Concerning Supplementary materials, I think that... & Mean & $S D$. & Rank \\
\hline 1 & $\begin{array}{l}\text { Supplementary materials (e.g. flashcards, posters, audio } \\
\text { materials, visual materials, homepage, etc.) are supplied and } \\
\text { made available to both teachers and pupils. }\end{array}$ & 1.56 & .757 & 4 \\
\hline 2 & The supplementary materials are at the level of the pupils. & 1.85 & .715 & 2 \\
\hline 3 & $\begin{array}{c}\text { The supplementary materials are used effectively by teachers in } \\
\text { their daily teaching. }\end{array}$ & 2.07 & .771 & 1 \\
\hline 4 & $\begin{array}{l}\text { The supplementary materials can be easily used within the time } \\
\text { span of the school period. }\end{array}$ & 1.83 & .803 & 3 \\
\hline 5 & $\begin{array}{c}\text { The teacher's guide is supplied and made available to teachers } \\
\text { to help them in their teaching. }\end{array}$ & 1.08 & .777 & 5 \\
\hline
\end{tabular}

\section{2}


Besides, the materials are used effectively and they were seen as suitable for the level of the pupils. However, this nice impression is spoiled due to the fact that materials are in most cases unavailable for teachers and that, in case made available, they cannot be used easily within the limited of the school period which does not exceed 35 minutes in most cases.

Teachers' articulations related to supplementary materials focused in most cases on the lacking of these materials altogether at their school contexts. This is clearly felt through the following comments:

'We just have the pupils' book and the workbook and that's it. We should have the audio material available. Pupils need to listen to how English is spoken by the native speakers. I myself need to check and improve my pronunciation before coming to the class".

Even in case the audio materials is made available, constraints based in school act against using them effectively, such as lack of facilities and time.

"Besides, even if you have the audio texts, we don't have the school facilities, I mean the players, to run these audio materials. That's why I read the texts aloud to my students, but if my pupils listen to them from native speakers, it will be much better".

In the same respect, almost all participating teachers complained about not having been trained on how to make good use of these audio materials or on how to teach these listening texts. This sometimes led to skipping listening activities and sometimes else to teaching them in the wrong way.

"We should've been trained on this textbook, especially how to teach the phonics and listening activities, before it came in to the schools. This is what we really lacked. It's like when you buy a new TV. You need someone to show you how to operate it or you will not be able to use it or break it down".

Research question no. 4

To what extent is TFE effective according to activities and exercises, as seen by teachers?

\section{3}


The activities and exercises represent the flesh of the textbook. They embody the enacting of theories and assumptions underpinning the textbook in practice. Data in Table (5) below show teachers' evaluations of the textbook activities and exercises. First in their evaluations came the variedness of the activities (i.e. individual, pair and group work); the liability of the activities for modification and supplementation; and the ability of these activities to enhance communicative use of the target language. Of moderate priority came the extent to which the instructions of the exercises are clear and understandable; and that the activities focus on promoting pupils' ability to produce authentic language and think critically. On the other hand, it was envisaged that there was a weak balance between free and controlled exercises; and the amount of exercises provided is not enough; and above all these activities cannot be executed within the time constraints imposed on the school timetable.

\begin{tabular}{|c|c|c|c|c|}
\multicolumn{1}{|c|}{ Table (5) Teachers' Evaluation of the Activities \& Exercises of TFE } \\
\hline & Concerning activities, I think that ....... & Mean & SD. & Rank \\
\hline 1 & $\begin{array}{c}\text { The textbook provides a balance of activities }(\text { e.g. } \\
\text { There is an even distribution of free vs. controlled } \\
\text { exercises and tasks that focus on both fluent and } \\
\text { accurate language production). }\end{array}$ & 2.12 & .675 & 7 \\
\hline 2 & $\begin{array}{c}\text { The activities encourage sufficient communicative } \\
\text { and meaningful practice. }\end{array}$ & 2.28 & .693 & 3 \\
\hline 3 & $\begin{array}{c}\text { The activities incorporate individual, pair and group } \\
\text { work. }\end{array}$ & 2.48 & .654 & 1 \\
\hline 4 & $\begin{array}{c}\text { There are a reasonable and appropriate number of } \\
\text { exercises in the textbook. }\end{array}$ & 2.09 & .745 & 8 \\
\hline 5 & $\begin{array}{c}\text { The instructions of the exercises are clear and } \\
\text { understandable. }\end{array}$ & 2.27 & .725 & 4 \\
\hline 6 & $\begin{array}{c}\text { The activities promote creative original and } \\
\text { independent responses. }\end{array}$ & 2.23 & .663 & 5 \\
\hline 7 & $\begin{array}{c}\text { The textbook's activities can be modified or } \\
\text { supplemented easily. }\end{array}$ & 2.38 & .678 & 2 \\
\hline 8 & $\begin{array}{c}\text { The activities can be practically implemented within } \\
\text { the duration of the English language period. }\end{array}$ & 1.90 & .774 & 9 \\
\hline 9 & $\begin{array}{c}\text { The exercises of the textbook promote critical } \\
\text { thinking of the pupils. }\end{array}$ & 2.15 & .753 & 6 \\
\hline
\end{tabular}

Teachers' articulations related to textbook activities and exercises showed that there was shortage of exercises that can give pupils enough practice on test-passing skills. Another complaint was that these activities and exercises are far beyond the pupils' current level. Their voices coincide with their responses to TEC. Two related comments are given below:

\section{4}


"There isn't enough amount of exercises that echo that pupils will see in the monthly or final exams. That's why pupils put the textbook aside when they study and go for the outside commercial course books".

"Most of activities and exercises are not at the level of the pupils. If you, I mean the teacher, insist on teaching them as the textbook suggest, you'll be like talking to yourself. The pupils' level is very low. This textbook should have gone to language schools instead of giving a severe shock to beginners like these".

Comments also emphasized that the activities and exercises are mostly of the display type and far from aiming to develop creative thinking. This is partially due to the bad effect of private lessons. This result is consistent with the teachers' responses to the TEC.

"These exercises are too simple and artificial. Pupils can answer them directly without too much thinking. New lessons are normally explained to the pupils before they come to school. You know private lessons. So, you, as a teacher, feel that you are blowing in the sea coz you feel that they know the answer to the questions you might pose".

\section{Research question no. 5}

To what extent is TFE effective according to skills and subskills, as seen by teachers?

Data in table (6) below reveal teachers' evaluations of the skills and sub-skills component of Time for English. Responses indicate that the textbook focuses on the pupils' ability to pronounce correctly through practice on stressing and intonation (i.e. phonics).

Table (6) Teachers' Evaluation of the Skills \& Sub-Skills of TFE

\begin{tabular}{|c|c|c|c|c|}
\hline & Concerning skills and sub-skills, I think that... & Mean & SD. & Rank \\
\hline 1 & $\begin{array}{c}\text { The materials include and focus on the skills that the } \\
\text { teacher and the pupils need to practice. }\end{array}$ & 2.24 & .705 & 5 \\
\hline 2 & $\begin{array}{c}\text { The materials provide an appropriate balance of the } \\
\text { four language skills (listening, speaking, reading and } \\
\text { writing) and sub-skills (grammar, vocabulary and } \\
\text { pronunciation). }\end{array}$ & 2.37 & .696 & 2 \\
\hline 3 & $\begin{array}{c}\text { The textbook highlights and practices natural } \\
\text { pronunciation (that is, stress and intonation). }\end{array}$ & 2.44 & .719 & 1 \\
\hline 4 & The vocabulary items are at the right level of the pupils. & 2.26 & .733 & 3 \\
\hline 5 & The textbook provides enough practice in handwriting. & 1.87 & .779 & 6 \\
\hline 6 & $\begin{array}{c}\text { The grammatical structures and vocabulary are presented } \\
\text { in authentic contexts and appealing contexts. }\end{array}$ & 2.25 & .722 & 4 \\
\hline
\end{tabular}

\section{5}


On the other hand, it holds a balance between the main skills and sub-skills of the target language, including vocabulary, which, as indicated by the data above, was envisaged as fitting the level of the pupils. Data also indicate that grammatical structures and vocabulary need to be presented in more authentic and appealing contexts with more chance to practice the learned material. What is mostly needed is a space for pupils to practice handwriting.

Teachers' articulations of their evaluation of the target language skills and sub-skills that the textbook suggest support their responses to the TEC. The informants tended to compare Time for English to other textbooks they used to teach. They confirmed that Time for English pays too much attention to correct the target language pronunciation and phonics, something that, they thought, was not well-considered by previous textbooks, yet representing a challenge to non-specialist teachers.

"Yes, the phonics sections are something new. There's too much focus on phonics. I'm a specialist and I know how to teach them, but what about the majority of the teachers who know nothing about ways of teaching phonics".

The above view justifies the teachers' responses to TEC which shows that the textbook material does not address the skills that teachers and pupils need to practice. An example of these skills and sub-skills is handwriting. Complaints arose from the interview participants emphasizing the need for the textbook to provide pupils with enough practice in handwriting since writing is a mean for communication. Concerning vocabulary, some of the teachers' responses confirm that most of the vocabulary presented is mostly new to them and reflects to a great extent the target culture.

"I feel embarrassed sometimes in front of my pupils when teaching new words that require some cultural knowledge to understand their connotations. I myself find some difficulty explaining the meaning of some of these words".

The time allotted to teach a particular textbook and the level of the learners can determine the vocabulary load and the teaching approach used by the teacher. Data analysis reveals that these

\section{6}


two factors should be taken into consideration. This was explained through the following comment

"A great number of new words are assigned for each lesson in this book. It's a hard work to teach them all in less than two hours a week. To overcome this problem I translate them into Arabic instead of using other techniques as I am restricted to the classroom time".

\section{Research question no. 6}

To what extent is TFE effective according to the language type, as seen by teachers?

The 'Language Type' component taps areas like the authenticity of the language and its appropriateness for the pupils' level; progression of vocabulary and grammar; and exemplification of the grammar points. Data in table (7) show that grammar and vocabulary items, as seen by teachers, are presented through easy and brief examples through real life situations. On the other hand, the progression of these items is less appropriate and the language used is not at the pupils' ability level.

Table (7) Teachers' Evaluation of the Language Type of TFE)

\begin{tabular}{|c|c|c|c|c|}
\hline & Concerning language type, I think that ....... & Mean & SD. & Rank \\
\hline 1 & $\begin{array}{c}\text { The language used in the textbook is authentic, that } \\
\text { is, like real-life English. }\end{array}$ & 2.36 & .694 & 2 \\
\hline 2 & $\begin{array}{c}\text { The language used is at the right level for pupils } \\
\text { current English language ability. }\end{array}$ & 2.18 & .728 & 4 \\
\hline 3 & $\begin{array}{c}\text { The progression of grammar points and vocabulary } \\
\text { items is appropriate. }\end{array}$ & 2.32 & .720 & 3 \\
\hline 4 & $\begin{array}{c}\text { The grammar points and vocabulary items are } \\
\text { presented with brief and easy examples and } \\
\text { explanations. }\end{array}$ & 2.39 & .687 & 1 \\
\hline
\end{tabular}

Interview responses related to 'Language type' used in the textbook compared it to the current low level of pupils' ability, something that represents a problem for both teachers and pupils. An exemplar pertinent comment says;

"The vocabulary of the book is quite difficult. Pupils from different socio-economic backgrounds have to study and memorize these difficult words, which are also difficult for teachers

\section{7}


sometimes, especially novice ones. We are supposed to teach words which are new to us and have never seen before. What about these children?"

Most of the informants highlighted the importance of the appropriate cultural contextualization in the presentation of new vocabulary.

"Teachers have to teach lessons addressing native culture without knowing the exact techniques of presenting them .What we need is to have sufficient training to teach these lessons. For example, you can find a lesson in Grade six entitled Welcome to New York City, the big Apple! This lesson is too hard for us to teach. What we need is just training ".

\section{Research question no. 7}

To what extent is TFE effective according to the subject and content?

Evaluation of the subject and content addressed questions of whether the topics are relevant and interesting for the learners or not, and what text types (i.e. dialogues, notes, songs, poems, essays, biographies, letters, newspaper articles, jokes, folktales, etc.) the textbook contains; and whether the texts in the textbook are authentic, up to date or not. Data in table (8) show that the content and topics of textbook and its associated components are culture- neutral, varied and relevant. Nevertheless, the topics need to be more motivating, realistic and challenging.

Table (8) Teachers' Evaluation of the Subject and Content of TFE

\begin{tabular}{|l|c|c|c|c|}
\hline & Concerning subject and content, I think that... & Mean & SD. & Rank \\
\hline 1 & $\begin{array}{c}\text { The 'subject and content' of the textbook is relevant } \\
\text { to the pupils' needs. }\end{array}$ & 2.25 & .742 & 3 \\
\hline 2 & $\begin{array}{c}\text { The 'subject and content' of the textbook is } \\
\text { generally realistic. }\end{array}$ & 2.15 & .695 & 5 \\
\hline 3 & $\begin{array}{c}\text { The 'subject and content' of the textbook is } \\
\text { interesting, challenging and motivating. }\end{array}$ & 2.09 & .696 & 6 \\
\hline 4 & $\begin{array}{c}\text { There is sufficient variety in the 'subject and } \\
\text { content' of the textbook. }\end{array}$ & 2.35 & .678 & 2 \\
\hline 5 & The topics and content represents the target culture. & 2.41 & .697 & 1 \\
\hline 6 & $\begin{array}{c}\text { The topics raise the interests of both teachers and } \\
\text { pupils in further English language study. }\end{array}$ & 2.18 & .726 & 4 \\
\hline 7 & $\begin{array}{c}\text { The topics included can be easily presented to } \\
\text { students. }\end{array}$ & 1.99 & .818 & 7 \\
\hline
\end{tabular}

\section{8}


Teachers' responses related to textbook subject and content provoke an important issue. Most teachers emphasized that the topics included cannot be easily presented to students specially the topics that address the American culture. They confirmed the idea that the cultural topics included in TFE are not easy for them to explain

"The topics included are about American culture. You can find lessons like "Welcome to New York city, The big apple ", " Ice cream in New York", "Welcome to Orlando" ...etc. that need different ways of instruction instead of the regular ones. We did not receive any training to teach such lessons. Besides, we as teachers need to be aware of these cultural issues so that we can teach them more effectively".

\section{Research question no. 8}

How far is TFE suitable according to the Egyptian context, as seen by teachers?

This section address issues related to the applicability and feasibility of the textbook in the Egyptian context and culture. Data in table (9) show that the teacher, as the main user of the textbook, is not proficient enough to teach it. Figures also show that though the textbook was seen as being suitable for the pupils' age, the Egyptian context and culture with its varieties are not well-represented in the textbook. Moreover, the current school context and the class size are not catered for.

Table (9) Teachers' Evaluation of the Suitability of TFE for the Egyptian

\section{Context}

\begin{tabular}{|c|c|c|c|c|}
\hline & Concerning Context and Ecology, I think that... & Mean & SD. & Rank \\
\hline 1 & $\begin{array}{c}\text { The Egyptian culture and its varieties (e.g. urban, sub-urban, rural, } \\
\text { desert, coastal, etc.) are well-represented in the textbook. }\end{array}$ & 1.83 & .807 & 3 \\
\hline 2 & The textbook is suitable for the current class size. & 1.68 & .732 & 4 \\
\hline 3 & The textbook is suitable for the pupils' age. & 2.12 & .754 & 2 \\
\hline 4 & The teacher is not proficient enough to teach the textbook. & 2.30 & .745 & 1 \\
\hline
\end{tabular}

Responses related to feasibility of TFE in the Egyptian context were numerous. They addressed issues like teacher quality, school context, cultural component of the textbook, etc. Most of the teachers working in the primary school are non-specialist. Due to shortage in EFL teachers, the teachers of other subjects are held responsible for teaching English with no prior training. Pertinent interview responses echoed those responses recorded earlier by the TEC. The gap between the requirements of the

\section{9}


textbook and the quality of the teachers was a common theme, as represented by the comment below:

"We are three teachers in the same school. I'm the only specialist here. That isn't fair for pupils who become a victim in the end. That's why they try to make it up through private lessons. It's not fair to teach a subject, especially English, without being originally a teacher of English. This wouldn't happen in any part of the world".

Moreover, they also mentioned that TFE is quite foreign and that "it shouldn't be taught at public schools. It can be suitable for pupils at language schools. What about pupils in our villages and in the desert? These areas are not represented".

Further responses by the interview informants could be categorized under a set of themes, most of which reflect a sense of dissatisfaction amongst teachers, while some of which reflect teachers' suggestions for improvement. Both categories of responses are summed up in table (10) below.

\section{Table (10) Some of the teachers' dissatisfaction points and their suggestions}

for improvements

\begin{tabular}{|c|c|c|}
\hline No. & Dissatisfactions & Suggested solutions \\
\hline 1 & The Vocabulary included are overloaded & Reducing the amount of vocabulary \\
\hline 2 & $\begin{array}{c}\text { Too much focus on phonics without teaching } \\
\text { them in the right way }\end{array}$ & $\begin{array}{l}\text { Provision of facilities and audio-visual } \\
\text { aids. }\end{array}$ \\
\hline 3 & $\begin{array}{l}\text { Teachers are not well-trained on teaching the } \\
\text { textbook. }\end{array}$ & Adequate teacher training sessions \\
\hline 4 & Lack of enough time for more practice. & More classes (i.e. time) are needed. \\
\hline 5 & $\begin{array}{c}\text { Lack of websites that foster learning } \\
\text { outcomes. }\end{array}$ & $\begin{array}{l}\text { Provision of a website that helps teachers } \\
\text { and pupils to get more information and } \\
\text { develop learners' autonomy }\end{array}$ \\
\hline 6 & $\begin{array}{l}\text { Not enough attention is not given to writing } \\
\text { skill }\end{array}$ & $\begin{array}{l}\text { More practice/weight should be given to } \\
\text { the writing skill, including handwriting. }\end{array}$ \\
\hline 7 & Items and topics are being replicated. & Deleting replicated topics. \\
\hline 8 & $\begin{array}{l}\text { Activities do not promote creative, original, } \\
\text { and independent responses. }\end{array}$ & $\begin{array}{l}\text { More activities that address creative } \\
\text { thinking should be provided and teachers }\end{array}$ \\
\hline 9 & $\begin{array}{c}\text { Language type far above teachers' current } \\
\text { proficiency level, especially non-specialized } \\
\text { teachers. }\end{array}$ & $\begin{array}{l}\text { Only specialized teachers should teach the } \\
\text { textbook. }\end{array}$ \\
\hline 10 & $\begin{array}{l}\text { Gap between topics and children's } \\
\text { environment and context. }\end{array}$ & More consistency is needed. \\
\hline 11 & $\begin{array}{l}\text { Large class size is a constraint against using } \\
\text { interaction through group or pair work. }\end{array}$ & $\begin{array}{l}\text { Establishing supplementary class sessions } \\
\text { and applying active learning strategies }\end{array}$ \\
\hline 12 & Lack of integration amongst items of units. & $\begin{array}{l}\text { Achieving integration between units' } \\
\text { construction }\end{array}$ \\
\hline 13 & $\begin{array}{l}\text { Lack of exercises that simulate questions of } \\
\text { final exams. }\end{array}$ & $\begin{array}{c}\text { Adding more exercises and drills in each } \\
\text { unit }\end{array}$ \\
\hline 14 & $\begin{array}{l}\text { Children's family background does not assist } \\
\text { the school efforts. }\end{array}$ & $\begin{array}{l}\text { Establishing monthly meetings with } \\
\text { parents for the purpose of following up. }\end{array}$ \\
\hline 15 & $\begin{array}{l}\text { Lack of experience in presenting lessons that } \\
\text { address the foreign culture. }\end{array}$ & $\begin{array}{l}\text { Giving sufficient teacher training } \\
\text { workshops about how to integrate culture } \\
\text { in foreign language classrooms. }\end{array}$ \\
\hline
\end{tabular}




\section{Discussion}

The present study attempted to evaluate the primary school EFL textbook "Time for English" provided by the Ministry of Education in 2013-2014 as a replacement of " Hand in Hand" from grade 1-3 and "Hello" from 4-6. Since the major users of the textbook are the students and teachers, their opinions toward textbooks should be ascertained and analyzed. Therefore, the researchers administered a Textbook Evaluation checklist (TEC) adapted from Litz (2005) and conducted semi-structured interviews trying to figure out teachers' opinions and views. The data gained from the TEC were approximately consistent with the data obtained from the semi-structured interviews. Both sources of data revealed several perspectives regarding the eight aspects of textbook evaluation.

Results gained from analyzing teachers' responses on the TEC and the semi-structured interviews revealed some virtues of "Time for English" regarding aspects such as; the cover of the textbook appeals to most students, the size, the weight and the title of the text book is appropriate, the layout and the design is suitable, the textbook is effectively organized, the textbook included detailed overview of the content area, it provided learners and teachers a glossary for all the included lexical items, the supplementary materials are at the learners' level. The activities involved in the textbook incorporate individual work, pair and group work. The activities encourage sufficient communicative and meaningful practice and finally "Time for English" managed to bring culture inside EFL classrooms. Such as presenting a lesson entitled "Welcome to New York City, the Big Apple!" in Grade six but with a superficial handling from most teachers due to lack of training.

EFL textbooks should be attractive. In this context, Harmer (1998) and Nunan (1991) emphasized that language teaching materials should be good to look at; the density of the page should be appropriate as well as the type size and the cohesiveness of the layout should be cared for. However, this was not taken into account in Time for English, as results revealed that 
the pictures introduced were to a great extent dull and the quality of printing was not suitable.

Data yielded from the semi-structured interviews with EFL teachers as well as the TEC revealed that most teachers did not receive any training on how to teach Time for English. Consequently, most teachers complained that they were not able to teach efficiently especially the exercises on listening or phonics which the textbook really emphasizes so their efforts have gone in vain. A textbook should be a teacher, a map, a resource, a facilitator and a trainer. It should provide novice teachers with confidence and security (Nunan, 1988; Cunningsworth, 1995; Ur, 1996 and Cortazzi \& Jin 1999). What makes matters worse is that most teachers did not receive sufficient feedback on their performance. Therefore, to fill in this gap the Teacher's Guide of Time for English should provide EFL teachers with appropriate instructions on how to teach all aspects of the target language.

EFL textbooks should provide sufficient supplementary and enrichment activities to students to give them enough opportunities to practice language. Unfortunately, in Time for English no time was devoted to practice any supplementary activities as the classroom sessions were only devoted for delivering the prescribed content. The teacher's guide did not provide teachers with adequate help in implementing these supplementary activities. Besides, there was a lack of training on how to use audio materials so conventional ways of instruction have been used.

Time for English did not offer sufficient activities and exercises that could foster students' critical and creative thinking although Ellis and Sinclair (1989) highlighted that EFL textbook should provide exercises for students to explore their own learning styles and strategies. Time for English did not provide students with authentic materials. Most lexical items and grammatical structures lacked authenticity. Pupils need to hear, see and read the way native speakers communicate with each other naturally. In this respect, Howard and Major (2010) assured that learners need to reflect the language and behaviors required of them in the world

\section{2}


outside the classroom. Hall (1995) confirmed that ideally language teaching materials should provide situations that demand the same situations where learners need to interact with each other regularly in a manner that reflects the type of interaction they will engage in outside the classroom.

Effective EFL textbooks should also offer opportunities for integrated language use. Bell \& Gower (1998) highlighted that ideally produced materials should give learners opportunities to integrate all language skills in an authentic manner and to become also competent at integrating extra-linguistic factors. Time for English paid much attention to natural pronunciation neglecting the development of students' handwriting. Developing students' productive skills did not receive much attention since most teachers' main concern was to recruit students for the exams regardless of developing students' communicative skills.

Time for English did not provide enough opportunity for promoting cross-cultural understanding. "If we understand other languages, but not their cultures, we can make fluent fools of ourselves" (Cakir, 2006). Teachers must be encouraged and trained to teach culture with small "c" by means of seeking, adapting, and if possible, designing culture-based materials through which pupils can develop their cross-cultural understanding. Teachers and curriculum designers should take advantages of real-life resources such as newspapers, literature, documentaries, history and movies to study topics related to race, discrimination, social class struggle and human rights. Therefore, teachers should be trained on how to develop students' global awareness, and integrate foreign culture with language instruction (Sadek 1995; Olaya \& Gomez 2013; Frenando; 2015; and Hamdy 2016). In this respect, it can be concluded that Time for English has introduced some cultural aspects that teachers would not efficiently able to present especially in Grade 6. This was confirmed by teachers' responses in the checklist as well as in the semi-structured interviews.

Finally, Time for English should be contextualized. In this sense, Nunan (1988) mentioned that effective teaching material

\section{3}


should be contextualized to the curriculum they are intended to address; and to the experiences, realities and first language of the learners. EFL textbooks should hold a balance between what teachers may regard as more enjoyable activities and those of a more serious nature. Materials should relate explicitly to what the learners already know, to their first languages and more importantly, should alert learners to any areas of significant cultural differences. Moreover, materials should be contextualized to topics and themes that provide meaningful, purposeful uses of the target language. Bell \&Gower (1998) highlighted that materials should be developed or chosen on the basis of their relevance and appropriateness for the intended learners to ensure personal engagement and to provide motivation for dipping further into the material. Unfortunately, most topics presented in TFE need to be more motivating, realistic, challenging and more host-culture relevant.

The evaluation conducted by this study is meant to be a comprehensive evaluation of the whole TFE series in context. All TFE textbooks levels were targeted. Thus, evaluation was not focused on the textbook mandated to a certain grade apart from other grades. This is because evaluation feedback was drawn from a variety of teachers teaching different grades of the primary school. In this respect further in-depth research might be needed to investigate the extent to which the findings drawn by this study apply to separate level textbooks within the same series.

\section{Conclusion}

The current study tried to offer a deep evaluative insight of Time for English from a constructivist perspective based on EFL teachers' lived experiences. It highlighted its strengths as well as its weaknesses for the sake of improvement.

Designers of teaching materials must first assess target learners' needs before introducing them new teaching materials. They must make sure that the newly introduced material really satisfies their needs, interests and abilities, and has the capability to develop their language skills and promote their critical thinking.

\section{4}


They must make sure that teachers are completely capable of presenting the content and possess the teaching skills for compromising the newly presented material with students learning styles, abilities and individual differences.

\section{Recommendations}

In light of the results of the present study, the following recommendations can be posed:

1. A reconsideration of using "Time for English" in the primary stage in terms of physical make-up, layout and design, supplementary materials, activities and exercises, language skills and sub-skills developed, language type, subject and content and finally the context.

2. EFL materials designers should conduct comprehensive needs assessment of the target audience (i.e. students, teachers and supervisors) before tailoring their teaching materials. They should have a sound understanding of the host culture in which their teaching materials will be used.

3. When planning activities to EFL students curriculum, designers are advised to take into consideration the following points confirmed by Shehata (2013: 145):

a. The developmental stage of students.

b. Students' individual differences.

c. Including activities that promote critical thinking, problem solving and develop language use.

d. Finding ways to incorporate culture with language instruction.

e. Designing enjoyable tasks to keep motivation high and reduce apprehension.

4. Training EFL teachers before introducing new EFL textbooks.

5. Supervision visits should be based on a sense of collegiality, and conferences between EFL teachers and their supervisors should be developmental in perspective rather than evaluative.

\section{5}


6. Emphasizing the role of social media networks in EFL teacher supervision and making use of their potential in bridging the communication-gaps between teachers and their supervisors.

7. Providing EFL teachers with sufficient educational resources and materials to achieve better student learning outcomes.

8. Using active learning methods and strategies in EFL classrooms.

9. Training EFL teachers on how to integrate the target language culture with small "c" inside EFL classrooms.

\section{Suggestions for further Research}

1. A Replication of the present study to be administered to a wide number of teachers and Governorates.

2. Analyzing the content of Time for English in light of the national academic and performance standards.

3. Investigating the different methods for developing teachers' professional development.

4. Using social media network for developing teachers' professional development.

5. Designing training courses for teachers for the implementation and evaluation of communicative activities.

6. Raising teachers' awareness of the importance of developing and evaluating students' productive skills.

7. Exploring EFL teachers' experience in integrating culture inside EFL classrooms.

\section{References}

- Ansary, H., \& Babaii, E. (2002). Universal characteristics of EFL/ESL textbooks: A step towards systematic textbook evaluation. The Internet TESL Journal, 8(2), February 2002.

- Retrieved December 12, 2015 from: http://iteslj.org/Articles/AnsaryTextbooks/ Azizfar, A., Koosha, M., \& Lotfi, A. R. (2010). An analytical evaluation of Iranian high school ELT textbooks from 1970 to the present. Procedia: Social and Behavioral Sciences, 3,36-44.

- RetrievedDecember11,2015from:http://www.sciencedirect.com/scien ce/article/pii/S1877042810013844.

\section{6}


- Barbour, R. (2014). Introducing Qualitative Research: A Student's Guide, London: Sage.

- Bell, J., \& Gower, R. (1998). Writing course materials for the World: A great compromise. In B. Tomlinson (Ed.), Materials Development in Language Teaching (pp.116-129). Cambridge: Cambridge University Press.

- Breen, M., \& Candlin, C. (1987). Which materials? A consumer's and designer's guide. In L. E. Sheldon (Ed.), ELT textbooks and materials: Problems in evaluation and development. ELT Documents 126 (pp. 13-28). London, UK: Modern English Publications and the British Council.

- Cakir, I. (2006). Developing cultural awareness in foreign language teaching. Turkish Online Journal of Distance Education-TOJDE, 7(3), Article: 12,154-161Charmaz, K. (2008). Constructionism and the grounded theory. In J. A.

- Holstein \& J. F. Gubrium (Eds.), Handbook of Constructionist

- Research (pp. 397-412). New York: The Guilford Press.

- Cortazzi, M., \& Jin, L. (1999). Cultural mirrors: Materials and methods in the EFL classroom. In E. Hinkel (Ed.), Culture in Second Language Teaching and Learning (pp. 196-220). Cambridge, UK: Cambridge University Press.

- Cunningsworth, A. (1995). Choosing your Coursebook, London: Longman.

- Denzin, N., \& Lincoln, Y. (2011). The SAGE Handbook of Qualitative Research. USA, Library of congress.

- Dominguez, L. M. (2003). Gender Textbook Evaluation. MA thesis, Centre for English Language Studies, University of Birmingham. Retrieved November 26, 2015 from http://www.birmingham.ac.uk/documents/collegeartslaw/cels/essays/s ocioling Ellis, G., \& Sinclair, B. (1989). Learning to Learn English. Cambridge: Cambridge University Press.

- Ellis, R. (1997). The empirical evaluation of language teaching materials. ELT Journal, 51(1), 36-42.

- Hall, D. (1995). Materials production: Theory and practice. In A. C. Hidalgo, D. Hall, \& G. M. Jacobs (Eds.), Getting Started: Materials Writers on Materials Writing (pp.8-14). Singapore: SEAMO Regional Language Centre. 
- Hamdy, A. (2016). The Effect of Using a Program of Global Issues on

- Developing Second Year English Majors' Global Awareness and Critical Thinking. M.A Thesis. Faculty of Education, Minia UniversityHamiloglu, K., \& Kahova, H. (2009).

- A content analysis on the vocabulary presentation in EFL course books. Ozean Journal of social Sciences, 2 (1), 43-54. Retrieved February 2, 2015 from http://ozelacdemyHarmer, J. (1998). How to Teach English. Harlow, Essex: Pearson Educational Ltd.

- Harmer, J. (1998). The Practice of English Language Teaching (3rd Ed.). New York: Longman.

- Howard, J., \& Major, J. (2010). Guidelines for Designing Effective English Language Teaching Material. Retrieved November 12, 2015 fromwww.paaljapan.org/resources/proceedings/PAAL9/pdf/Howard.p df.

- Hutchinson, T., \& Waters, A. (1987). English for Specific Purposes: ALearning-Centred Approach. Cambridge: Cambridge University Press.

- Jahangard, A. (2007). Evaluation of EFL materials taught at Iranian public high schools. ELT Journal, 9 (2), 130-150.

- Kayapinar, U. (2009). Coursebook evaluation by English teachers. Inonu University Journal of the Faculty of Education, 10(1), 69-78.

- Litz, D. (2005). Textbook Evaluation and ELT Management: A South Korean Case Study. Retrieved July 12, 2015 from http://asian-efljournal.com/6177/thesis/2005/11/textbook-evaluation-and-eltmanagement-a-south-korean-case-study-2/ McDonough, J. \& Shaw, C. (2003). Materials and Methods in ELT: A Teacher's Guide. Malden, MA: Blackwell Publishing.

- McGrath, I. (2002). Materials Evaluation and Design for Language Teaching. Edinburgh: Edinburgh University Press.

- Nunan, D. (1991). Language Teaching Methodology: A Textbook for

- Teachers. Hertfordshire: Phoenix ELT.

- Olaya, A., \& Gómez, L. F. (2013). Exploring EFL Pre-service Teachers' Experience with cultural content and intercultural communicative competence at three Colombian Universities. Profile Issues in Teachers' Professional Development, 15(2), 49-67.

- Papajani, J. (2015). The evaluation of the EFL textbooks used in the high schools of Elbasan, Albania. European Journal of Language and

\section{8}


Literature Studies, 1(1), 7-15. Retrieved November 14, 2015 from: http://ejls.euser.org/index.php/layout- 3/135-evaluation-of-efl.

- Ranalli, J. M. (2002). An evaluation of New Headway UpperInterchange.

- Retrieved Novermber 5, $\quad 2015$

from http://www.cels.bham.ac.uk/resources/essays/Ranalli3.pdf.

- Richards, J. C. (2001). The Role of Textbooks in a Language Program.

- Cambridge: Cambridge University Press.

- Richards, C. J. (2016). The Role of Textbooks in a Language Program, Retrieved January 1, 2016 from http://www.professorjackrichards.com/articles/role- of-textbooks/ Sadek, S (1995). A Program of Training English Majors of the Faculty of Education in Small "c" Target Culture and its effect on Developing their Language Proficiency, Cultural Knowledge and Attitudes Towards the Target Culture. Unpublished M.A Thesis, Faculty of Education, Minia University.

- Sahragard, R., Rahimi, A., \& Zaremoayeddi, I. (2009). An in-depth evaluation of interchange series (3rd Edition). Porta Linguarum, 12(1), 37-54.

- RetrievedDecember11,2015fromhttp://www.ugr.es/ portalin/articulos /PL\%20issue12\%20Jun2009.htm.

- Shehata, M (2013). "The Effectiveness of an E- Conversation Course in Developing Faculty of Education English Majors' Aural-Oral Communication Skills, Cultural Awareness and in Reducing Oral Communication Apprehension". Ph. D Dissertation. Faculty of Education- Minia University.

- Sheldon, L. (1988). Evaluating ELT textbooks and materials. ELT Journal, 42(4), 237-246.

- Tok, H. (2010). TEFL textbook evaluation: from teachers' perspectives.

- Educational Research and Review, 5 (9), 508-517.

- Ur, P. (1996). A Course in Language Teaching: Practice \& Theory.

- Cambridge: Cambridge University Press.

- Vellenga, H. (2004). Learning Pragmatics from ESL \& EFL Textbooks: How Likely? TESL-EJ, 8(2), 1-18.

\section{9}


- Venezky, R. L. (1992). Textbooks in School and Society. In P. W. Jackson (Ed.), Handbook of Research on Curriculum (pp.436-461). New York: Macmillan Publishing Company.

- Weir, C., \& Roberts, J. (1994). Evaluation in ELT. Oxford: Blackwell.

- Williams, D. (1983). Developing Criteria for Textbook Evaluation. ELT Journal, 37(3), 251-255.

- Woodward,A. \& Elliot, D.L (1990). Textbook Use and Teacher Professionalism: Textbook and Schooling in the United States. University of Chicago Press.

- Woodward, A., \& Elliot, D. L. (1990). Textbook use and teacher professionalism. In Textbooks and schooling in the United States (Eighty-ninth Yearbook of the National Society for the Study of Education, Part 1) (pp. 178-193). Chicago: University of Chicago Press. 